PUBLICACIÓN ANTICIPADA EN LÍNEA (Versión previa a la corrección de estilo y diagramación). La Revista Tesis Psicológica informa que este artículo fue evaluado por pares externos y aprobado para su publicación en las fechas que se indican en la siguiente página. Este documento puede ser descargado, citado y distribuido, no obstante, recuerde que en la versión final pueden producirse algunos cambios en el formato

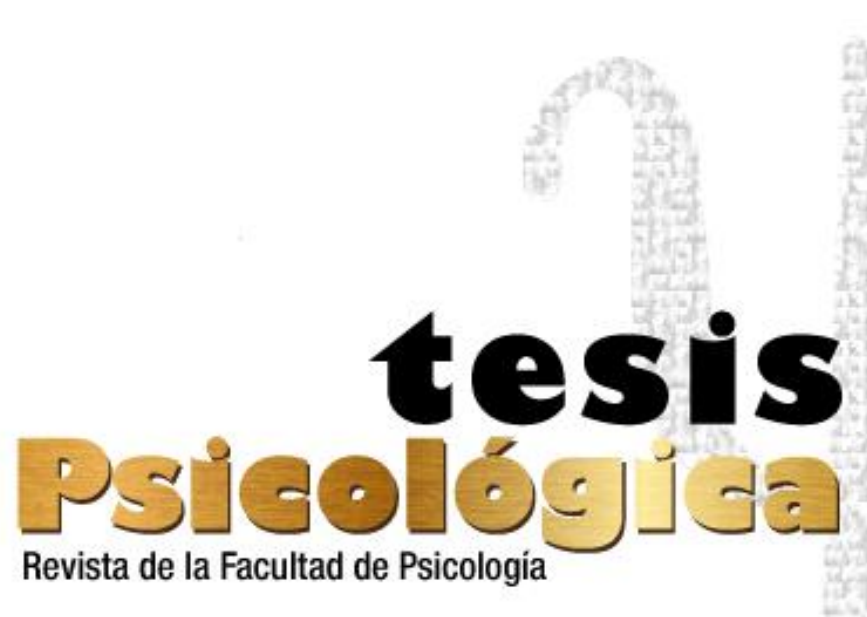




\title{
We, the disturbing animal: effects of anthropogenic noise in a Brazilian zoo
}

\author{
Patrícia Ferreira Monticelli ${ }^{1}$ \\ Ana Carla Medeiros Morato de Aquino ${ }^{2}$ \\ Bruna Campos Paula ${ }^{3}$
}

Recibido: julio 6 de 2021

Revisado: julio 8 de 2021

Aprobado: enero 11 de 2022

Cómo citar este artículo: Ferreira Monticelli, P., Madeiros Morato, A.C. \& Campos, B. (2022). We, the disturbing animal: effects of anthropogenic noise in a Brazilian zoo. Tesis Psicológica, 17(1), 1-33. 10.37511/tesis.v17n1a5

\begin{abstract}
The negative effects of loud anthropic sounds on non-human health and welfare urges attention. We report here the results of a technical study we conducted attending a Public Prosecutor's request at Ribeirão Preto, SP, Brazil. A Civil Inquiry informed against nocive effects of human concentration on captive and free-living animals around the municipal zoo. The zoo is part of a natural protected area that paradoxically was used as a locale for public festivities. We aimed to compare two weekends, one of a traditional Italian event (EV) and another with no event (NE), and check sound level and behavioral changes in a sample of captive animals and in the soundscape. We employed three procedures: (1) Sound Pressure level (SPL) assessment at different localities; (2) Comparative behavior analysis; and (3) Soundscape description. Our results provided cues of how the festivities may be affecting free-living animals in the APA Morro do São Bento and captive ones. Peak SPL exposure was higher in EV in almost all the localities of the zoo; the six monitored individuals (two ocelots, two crassow, the European cervid and the maned-wolf) changed their activity and resting patterns and the soundscape was more diverse and intense in vocal activity than in NE.
\end{abstract}

Keywords: Anthropocene; Cervidae; Communication; Cracidae; Maned wolf, soundscape.

${ }^{1}$ Departamento de Psicologia, Facultade de Filosofia, Ciências e Letras de Ribeirão Preto, Universidade de São Paulo, Brasil. Correspondencia: monticel@usp.br

${ }^{2}$ Divisão Funcionamento de Ecossistemas Tropicais, Centro de Energia Nuclear na Agricultura - CENA-USP, Universidade de São Paulo, Brasil.

${ }^{3}$ Departamento de Psicologia, Faculdade de Filosofia, Ciências e Letras de Ribeirão Preto, Universidade de São Paulo, Brasil. 


\section{Introduction}

The human being is a disturbing species. Many of our activities produce loud sounds (Chepesiuk, 2005) that are not even part of our communicative system. Some of them are pollutants that risk our health and concern the World Health Organization (Schwela, 2001). Human noise disturbs more than our own life. The effect of loud and pervasive anthropic sounds increases research issues in behavioral sciences and conservation (Slabbekoorn and Ripmeester, 2008; Barber, Crooks \& Fristrup, 2010; Blickley \& Patricelli, 2010; Barber et al., 2011; Francis and Barber, 2013).

The communication signals were selected throughout the evolutionary history of the species due to their consequences on the emissor's fitness (Lorenz, 1958), and maybe also on the receivers' and eavesdroppers' (Guilford \& Dawkins, 1991; Grinnell \& McComb, 2001; Monticelli, 2021). The production of a signal, especially the acoustic one, requires energetic investment and risks the emissor to predation by making it locatable (Bradbury \& Vehrencamp, 2000). So, vocalizing is a cost decision; all the sounds we hear in a zoo should be seen for their importance to the individual who decided to use them. They are not random screams and neither are they meant to make us happy or angry. They are part of the sensory world of other species.

In acoustic species, sounds that mask communication signals or reduce the distance over which acoustic signals can be perceived, interfere with individual decisions and social coordination of activities involved in foraging, mate selection, territory defense, and antipredation strategies (in avian: Slabbekoorn and Ripmeester, 2008; and mammals: Chan and Blumstein, 2011; Duarte, Vecci, Hirsch \& Young, 2011). Among anurans, birds, aerial, terrestrial, and aquatic mammals are species able to alter their acoustic signals structure to avoid or reduce masking effects of noise (Brumm and Slannekoon, 2005; Patricelli and Blickley, 2006; Warren et al., 2006; Ey \& Fischer, 2009; Parks et al., 2012). Unfortunately, this cognitive plasticity is not an ability of the majority of species, and those that are not able to adjust or move (Stankowich, 2008; Fidino et al., 2020), will be affected and there may be consequences to the community and biodiversity parameters (Barber et al., 2010).

Besides the effects on acoustical communication, noise has negative effects on hearing (Sliwinska-Kowalska and Davis, 2012; WHO, 2017), and hearing is required to survive (Stankowich, 2008; Barber et al., 2010). Alligators, lizards, robins, birds-of-prey, and bats use auditory cues produced by their prey in hunting (Payne, 1971; Rice, 1982; Neuweiler, 1989; Montgomerie \& Weatherhead, 1997; Carr \& Christensen-Dalsgaard, 2015). Hearing loss in free-living animals may kill them by hunger. 
Loud sounds may also have nocive effects on the health of human and non-human animals (WHO, 2017). To illustrate, all the eighth laboratory rats daily subjected to a brief 15 min exposure to white noise $(90 \mathrm{~dB})$ suffered disruption of the intestinal mucosa in only three weeks (Baldwin et al., 2006). Male rats' immune functions were also affected over time by low-intensity chronic intermittent and unpredictable noise $(10 \mathrm{~h} / \mathrm{day}, 15 \mathrm{~min} / \mathrm{h}$ over three weeks), both immune suppression and enhancement (Van Raaij et al., 1996). For instance, serum IgM levels were increased and peripheral phagocytic activity was decreased after only $24 \mathrm{~h}$ of exposition to the protocol routine.

The World Health Organization reference levels for safety in noise exposition are rarely attended to in automotive traffic, the concentration of talking people, and music concerts (Schwela, 2001). Even at home, we are not safe. Listening to loud music is a widespread behavior that issues public health worldwide, as young people may experience hearing loss, impacting in cognition and language acquisition with consequences in social living and employment opportunities (WHO, 2017; Graydon et al., 2019).

The Brazilian Association of technical regulations (ABNT) for noise levels in inhabited areas (NBR 10.151 and NBR 10.152) aims at "the comfort of the community" (only humans). For instance, NBR 10.151 states that the loudspeakers used in musical concerts and truck passing produce sound at unhealthy levels (to humans); it would take less than 15 minutes of exposure to get hearing damage (ABNT Acústica 2000). The animals with equivalent hearing abilities (like terrestrial non-human mammals and avians) may suffer the same nocive consequences. Our National Environment Council - CONAMA (n. 9,605/98, CONAMA resolutions 001 and 002/90) establishes provisions for the National Program for the Education and Control of Sound Pollution. However, the regulations are applied within urban areas, considering the human beings and health, safeguarding the right to environmental comfort. The regulations and resolutions to control the damage effects of sound pollution on non-human animals' wellbeing and health, some of them living close to us, as pets, in zoos, or cohabiting urban spaces, are lacking in Brazil.

The present article is part of a report that documents the technical evaluation results we conducted attending the Public Prosecutor's request at Ribeirão Preto, state of São Paulo, Brazil. A Civil Inquiry informed against nocive effects of human concentration and noise pollution on captive and free-living wildlife in the municipal zoo. The zoo is part of a natural protected area that paradoxically was used by the mayor as a suitable locale for public festivities. Therefore, in attendance to the official request, we aimed to (1) assess the noise pressure level of the party installation and activities at different points of the zoo and adjacent 
area; (2) check behavioral changes in a sample of captive birds and mammals during parties, comparing it against a control situation, like a weekend with no festive event held in the area.

\section{Material and Methods}

\section{Study area}

Zoológico Fábio Barreto (ZFB) is located in Ribeirão Preto ( $\left.21^{\circ} 10^{\prime} 42^{\prime \prime} \mathrm{S} ; 47^{\circ} 48^{\prime} 24^{\prime \prime W}\right)$, one of the largest cities of São Paulo, Brazil. It is a city of more than 600,000 inhabitants, $330 \mathrm{~km}$ from the state capital, and is among the most deforested Brazilian cities; its green area is reduced to less than $4 \%$ of the original coverage (Kotchetkoff-Henriques et al., 2005).

The ZFB is part of a legally established Environmental Preservation Area (APA, Portuguese), named Parque Municipal Morro do São Bento (PMMSB). The APA Morro do São Bento was created in 1988, and in 1995, the PMMSB was established there, consisting of the zoo, two theaters, and a sports square (Kotchetkoff Henrique et al., 2018). The PMMSB should be conserving the APA biological integrity in its ecological aspects and promoting Environmental Education. BHowever instead, it was for long adopted as an open public place for street festivals.

\section{Procedure}

The city hall cultural schedule pointed to the Festitália, an Italian traditional commemoration event, as the next event to be held in the PMMSB. Therefore, we obtained authorization and security support from the zoo's in-charge director to conduct recordings and noise level measurements on that occasion (a weekend starting on August 5th, Friday, in the year of 2016; see Festitalia schedule on Table 1) and a subsequent weekend (the control situation for comparison, starting one month later, at September 2nd).

We employed three procedures: (1) Sound pressure level (SPL) assessment at different points of the ZFB and adjacent areas; (2) Comparative behavior analysis at the event (EV) and non-event (NE) conditions for a sample of species, among avians and mammals, that was pointed by the zoo staff as those that would be sensitive to noise; and (3) soundscape comparison. Behavior was obtained through vídeo recording and analyzed under the ethological approach.

The SPL was measured through a decibel meter, an instrument developed to monitor loudness in decibels in occupancy areas by manufacturer industries and contractor companies 
(Dwisetyo et al., 2021). To evaluate noise damage to human hearing, the ABNT requires the measurement with a correction, the A-weighting curve (dBA). It is the best approximation to the human ear logarithmic perception of sound; dBA reduces the lower frequency values of environmental noise to adjust to our perception that is bad at lower acoustic frequencies (e.g., in $200 \mathrm{~Hz}$, the SPL in reduced in $10 \mathrm{~dB}$ and that is the value used to evaluate de nocive effects to humans; Musafir, 2014) (Wong, 2010; Ordoñez et al., 2010; Burg et al., 2017). This Aweighting curve ignores the impact of SPL over non-human hearing systems (Dwisetyo et al., 2021). Therefore, we adopted the C-weighting that is used to assess loud impulsive sources peak sound pressures, like people speaking on a microphone. By way of comparison, the background noise is commonly 10 to $15 \mathrm{~dB}$ in $\mathrm{dBC}$ above the $\mathrm{dBA}$ value, which reduces the sound bass. To the loud intensity noises, the European noise regulamentation establishes that it should not exceed 85dBA for daily exposition or $137 \mathrm{dBC}$ for peak exposition for working places (Wong, 2011). We adopted these values as parameters for our study.

We performed the SPL measure at 12 locations (see distribution map in Figure 1). Each location was visited two times in a day: on a first tour from point 1 to 12 , we took ten independent measurements of SPL. For covering the broad frequency spectrum of non-human animals' hearing (Table 2), we measured in C-weighting curve (dBC), fast response circuit (FAST), and in Leq (equivalent to a continuous sound level; Rossing 2007) and the range of 50-110 dB. After visiting all the other 11 locations, we came back to the first and repeated the ten independent SPL measurements. In other words, on Saturdays (one during Festitália and another on the non-event weekend), we went around the 12 locations two times, and on each time, we registered 10 SPL values at 10 -sec intervals. The second visit round occurred one hour later. We calculated the mean, the standard deviation, and minimum and maximum SPL values of the locations to compare EV and NE conditions.

We used six Bushnell@ camera traps (AF) to capture behavior in the enclosures in EV and NE conditions. This equipment has a motion sensor that once triggered records on video according to its sets. Infrared illumination allows for a good image even in low light. We set the AFs to shoot for 20 seconds whenever triggered, and ignore new movements for a 5-minute break: once triggered, the camera recorded 20 secs and did not register the same or new movements in front of the sensor for 5 minutes. From the installation until their removal, the cams recorded continuously from the end of the afternoon of Friday until the end of the morning 
of Monday. The cameras were installed in six enclosures, some of them with more than one species (Figures 1,2).

We also installed a passive acoustic monitoring unit (PAM) in a central area inside the zoo, expecting to register captive and free-living species vocalizations. Animals use different sounds according to their mood and environmental stimulus and recognizing the calls would help us to capture different reactions on EV and NE conditions. A Wildlife Acoustics@ Automatic Recorder Model Songmeter 3 (SM3+) was installed in the area of the quarantine sector, in front of the Biology building, to the right of the Veterinary Hospital (Figure 1). In the quarantine sector, there were several avian, including hawks, owls, Jandaya Parakeet, Macaws, and Potoo, and the mammals Lycalopex vetulus fox, two maned wolves, a baboon (removed from visitation for its sensitivity to contact with the public), and young collared peccaries. Free-living species like the howler monkeys, marmosets, and peacocks would also be captured by the wide recording range of the PAM. The SM3+ was fixed on a tree 1.5 meters from the ground, set to record continuously from 5 pm to 5 am (12 hours) on Fridays EV and NE. The digital recordings were obtained in two channels, in a sample rate of $44.1 \mathrm{kHz}$ (i.e., capturing sounds until 22kHz), $36 \mathrm{~dB}$ gain, and in 16-bit files saved on secure digital (SD) cards. The audio recording used the waveform audio format (.wav) fragmented in 30-min segments, to make the spectrogram analysis faster. After PAM installation, there was no need to check its functioning; it has huge energetic (D batteries) and data registering capacities.

Vídeo recordings had to be checked at least once after installation and we did it on Saturdays (batteries charges and focalization adjustment when necessary). The recorders were removed on Mondays. On Saturdays (August 6th and September 3rd), we performed the SPL measurements in the time interval of 7 to 9 PM, when the musical performance started.

\section{Equipment}

The decibel meter was the INSTRUTEMP ITDEC-4080 (INSTRUTEMP®) calibrated immediately before taking measurements, with its specific device. This decibel meter complies with the requirements of the International Electrotechnical Commission standard (IEC 616721:2003, according to the INSTRUTEMP Manual). The camera traps (AF) were the model 8MP Trophy Bushnell@ that saved the records on one SD card. The passive sound recorder was a Wildlife Acoustics@ Automatic Recorder Model Songmeter 3 (SM3+, Wildlife Acoustics, Inc., Concord, Massachusetts) that also used SD cards (1 to 4 spots). 


\section{Results}

\section{Sound pressure measurement}

The results of the evaluation of the sound pressure level in the 12 locations obtained on Saturdays 6th August (EV) and 3rd September (NE) are shown in Table 3. The mean values were calculated based on the measurements taken every 10 seconds. The first three localities in Table 3, were the closest to the speakers outside the ZFB. At the stage, we were about 3 meters away and facing the speaker (front) or seeing it from behind. Even without the band playing, speaking into the microphone alone produced high values of peak exposure in $\mathrm{dBC}$. The absolute values of the $\mathrm{dB}$ data measured in the condition with and without band, on Saturday at Festitalia, are actually similar from each other regardless of the measurement location.

Inside $\mathrm{ZFB}$, the average sound intensity was never below $70 \mathrm{dBC}$ during the wide range of sound frequencies produced by the band's performance, except in the capybara's bridge, the farthest from the source and also the lowest in altitude. The simple speech into the microphone came to produce worrying values in areas with animals in recovery: peaks (maximum values) of 70 to $78 \mathrm{~dB}$ in the water tank (near the quarantine sector), and in the back window of the veterinary hospital building.

\section{Behavior assessment}

We recorded different taxons (a mustelid Eira barbara, anteaters Myrmecophaga tridactyla, two other cervids and those presented in Table 4). For different reasons, we present here only the results of the behavior analysis of the species in Table 5. The locations of their enclosures in the zoo can be seen in Figure 1. All the cam traps were programmed to record a 20s vídeo when the movement-sensor was activated and did not activate again before a 5-min interval among shoots. The number of videos produced per day varied in some ways (Table 4): the installation and removal moments varied among the enclosures, considering the time we took to finish one and go to the following; SD cards had failed in some periods; the area of the enclosures varied among species, but minimally between EV and NE.

We adopted a general ethogram super-classified as Activity (foraging, attention, locomotion, moving without displacement, hiding, self-oriented behaviors and elimination, stereotypic behaviors, playing) and Resting (sleeping, lying down, relaxed seated or standing). Behavior patterns particular to the species were registered in one of these categories and cited in the text. The consulted literature for behavior patterns and functionality was: Srbek-Araujo 
et al. (2012); Sick (1970); Rodden (2007). The results will be presented separately by species, to consider their particularities. Our aim was the comparison of EV and NE and not species against each other.

In table 4, we present the number of vídeo recordings in the SD cards per day and species. The vídeo registry occurred when the animal movement activated the cam trap sensor (shoots). So, we used the number of shoots as a comparable index of the activity of the focal individuals in EV and NE weekends. The shoot rate is the number of videos per recording period that varied from 7 to $24 \mathrm{~h}$, according to the installation and removal time of the camera. We watched all the videos produced by the shoots and excluded from this count those that could not have been produced by the focal animals (i.e., those in which the animal was not seen or was resting and there were rats, humans, or other animals passing by, Figure 2). In most cases, the shooting rate was higher in the EV situation than in NE, and this higher shooting rate agrees with the activity versus resting patterns identified using the ethogram. The carnivores had shooting rates not easy to compare: the maned wolf and the ocelots use to need welfare conditions that the Brazilian zoos rarely can provide. Thus, some recordings errors limited NE samples for comparison.

\section{A. European deer Dama dama}

It was an adult male recovering from a wound at the base of the horn. The animal was housed in an enclosure between the ocelots and the Biology building, which had an open and a closed area (a resting room covered with hay; see Figure 2). The camera trap was attached to the window and filmed practically the entire closed area, but it did not film the outside area. All the time the animal came from outside, the camera shot and served as indexes of the movement intensity of the animal. We got 116 videos in EV, from Saturday to Monday (there was no record on Friday) and 140 in NE (from Friday to Monday). On Saturday, the number of shots per hour in EV was twice the NE; in the second, there is practically no difference. But on Sunday the opposite was observed: there were 1.3 times as many shots/h in NE.

In Figure 3, we present an analysis of the animal's behavior associated with rest and foraging (obtaining nutrients by searching, chewing and, in this case, species, rumination). The behaviors are presented in percentage. The deer hardly rested, nor did he feed in EV and spent a huge percentage of its time moving around. We noticed five events of vocal behavior, one on NE, while lying and the others in EV during locomotion, grooming and stretches. The music was playing in three events. 


\section{B. Curassow and horse curassow Crax fasciolata and Crax sp}

There were two adult males, separated from each other by a fence rail, one better focused by the camcorder (Crax fasciolata), and used to behavior quantification. Behaviors were that compounded the categories were climbing the perch or lying down on the ground (resting); scratching the ground, walking with your head down (foraging), stop and stand still or nodding, alarm calling (attention), social behaviors (other calls, interaction through the grid) and locomotion (slow locomotion, locomotion from one side to another) and other activities (moving without displacement, self-cleaning). Figure 4 presents the relative frequencies of behaviors. We did not compute the videos resulting from shots caused by rat movements in the enclosure. EV and NE Fridays are not presented due to their small sample of data (the cam trap was installed at 5:30pm and the animals went soon to perch).

The animal was more attentive (standing up with head movements and alarm calling) on EV and walked more on the floor (Figure 4). They vocalized in 12 videos on EV, half of them were identified as alarm calling, three of them on Friday night while the band was playing (between 10:55 and 11:03pm). On NE, there were 8 videos with vocalizations, three of them were identified as alarm calling, four as contact calls and one accompanied an aggressive display. Resting values were more frequent on EV but it was due to the number of interruptions on their resting: every time they left the perchs, they went again to them later and it highered the frequency of restin; in NE, once the animals went to the perches at the end of the day, they went down again only once.

\section{Maned wolf Chrysocyon brachyurus}

There was a young adult maned-wolf kept in the quarantine area, waiting for a new enclosure. His enclosure was divided in two similar parts in space and configuration, except for that the food was offered in the left size, and the resting place was on the right side. He was there for at least one year in a $50 \mathrm{~m}^{2}$ enclosure.

The cam trap or the SD-card we used there did not work well. On EV, nothing was recorded on the first day (August 5), and on NE there were reduced recording intervals ( $8 \mathrm{~h}$ on Friday and 8h on Saturday) (Table 5). So, we have a small window for comparison: EV Sunday and NE Saturday between 7:00am to 1:00pm, and Ev and NE working days (Monday and Friday, respectively) between 11:50am to 5:30pm. There were 18 shots (movement sensor activation for recording) on $\mathrm{EV}$, and in 6 of them the maned-wolf was resting (sleeping or standing still). In that same interval and period of the day (hot in the city), there were 30 shots 
in NE condition, but in 23 of them the animal was resting. Comparing the weekend days, there were 55 shots on $\mathrm{EV}$, and in 30 of them the maned-wolf was resting; on NE, there were 60 shots and in 33 of them the animal was resting. We noticed what seemed to be a stereotypy only in NE (10 of the 27 events of his activities were locomotion through all the enclosures in a repeated circuit).

The behaviors emitted in the activity time were foraging (scratching the ground, eating, drinking, walking with head down, walking with food in the mouth), attentive (stop and stand still, lateral movements of the head, ears up and moving) and agitated (walking frantically from one side to other or walking sideways), resting plus observing (standing and following humans movements, sniffing the wall or floor while lying down and upright sniffing around, and grooming), moving (locomotion, moving slowly with lowered head, moving without displacement, circling before lying down and scratching the ground, head-shaking, yawning and stretching) and interacting with objects (he used a piece of wood, the food tray, hope and knocked the ground and playing-hunt over the wooden he used to rest) (Figure 5). There were two episodes of vocalizing, one on each condition and they growled with ruffled fur when a man approached.

\section{Ocelots Leopardus pardalis}

There were two male ocelots of the same size. One that rested more than the other, that exhibited a stereotyped walking and rested less. Like we did in the maned-wolf, we grouped all the EV moments (saturday to monday) and all the NE (friday and saturday) and presented it in Figure 6, in relative frequency. Dos 39 registros de descanso em EV, em apenas quatro os dois ocelots estavam descansando. Nos outros 35, o animal mais agitado estava andando. o descanso The cam trap position in EV permitted us to see a male Eira Barbara when he was walking in his stereotyped circuit, from a non-visible part of the enclosure to the part we could see. The food was put in the visible part also. With these observations we noted that from Saturday 2:40pm to Monday 2pm (almost 48h) the animal visited the food box and ate five times, three on Saturday. The stereotyped walking behavior occurred in intervals varying from one to three hours almost uninterrupted, on Saturday from midday to $1: 15 \mathrm{pm}$, then again at $3 \mathrm{pm}$ after food delivery for one more hour. On Sunday, from 7:30 to 10am and again at 11am, for one more hour, and again from 1:44pm to 16:51. 


\section{Soundscape}

Table 5 presents a list of the sounds identified in the recordings of Fridays EV and NE. We count the occurrences (number of vocal episodes per type of sound and species) of vertebrates in the recordings in one-hour time intervals. Comparing the total number of occurrences, there were more vertebrate occurrences in NE than in EV, except in the later time interval (from 11:50pm-00:50am). In all the time intervals (except one), the number of species calling was higher in EV than NE, and reduced from the earlier to the later intervals, what was expected for the diurnal species. But it is notable that diurnal species vocalized also late in EV friday (9:50pm-00:50a); they were parrots, arara, saracura, aramids. Lion, maned-wolf and the avian saracura (an aramid, a genus of birds in the family Rallidae) called only in EV condition. There was also a higher occurrence of peacock vocalizations in NE than EV, most of them were a loud meow that the male emits as a long-distance call to signal his territory and draw the females closer to him.

\section{Discussion}

The effects of loud sound on wild captive animals cannot be estimated by zoo veterinarians, without specific analyzes for the evaluation of endocrine parameters. These analyzes have a cost of time and money that can be replaced by behavioral analysis. In Brazil, vets rarely receive training for that. In many undergraduate courses, Ethology is not even in the curricular basis. In contrast, environmental sound recordings and studies constitute a relatively new approach is Ecology and Conservation, the acoustical ecology and the soundscapes analysis (Pijanowski et al., 2011), with a non-invasive and cost-effective method for studies. Captive animals do not need to forage for food, nor do they have the chance to attract a sexual partner. Nevertheless, being deprived of performing species-typical behavior diminishes the animal welfare state (Broom, 2011), causing stress, a physiological condition of loss of homeostasis associated with deviations in endocrine parameters (Möstl \& Palme, 2002). When they become chronic, these deviations alter immune responses which is a problem for animals recovering from surgery or undergoing medical treatment in a zoo.

The zoo of the municipality of Ribeirão Preto, SP, besides all the issues a Brazilian public institution is contingency to, and despite being in an ecological protected area, was subjected to the loud noise of public festivities. We were asked if the festivities contingencies would impact animals health and for our expertise on behavior and bioacoustics, we hypothesized that noise pollution would impact on the animals welfare and that it could be seen 
in their activity/rest patterns: they would get restless during the parties and would drag the chronobiological rhythm of vital behaviors such as foraging (obtaining food by searching and ingesting, ruminating) and rest (laying down, sleeping). From the premise that the "Festitália" was the only important difference between test and control situations, the differences between them would be effects of the interest variable (the noise generated by the anthropic activities of the 11th "Festitalia" at PMMSB).

Our results provided cues of how the festivities may be affecting free-living animals in the APA Morro do São Bento and captive ones. Peak SPL exposure was higher during the EV than NE in almost all the localities of the zoo; the six monitored individuals (two ocelots, two crassow, the European cervid and the maned-wolf) changed their activity and resting patterns and the soundscape of the zoo changed.

The simple speech into the microphone came to produce worrying values in areas with animals in recovery; the water tank, for instance, is near the quarantine sector where the European deer was and a female marsh deer with a calf and a capybara in treatment, and the back window of the veterinary hospital building, where occasionally animals spend the night recovering from surgery or taking medication. Long time expositions could possibly cause intense irritation in humans and risk our health (Wong, 2011). During the show, a hospitalized animal would receive up to $87.7 \mathrm{~dB}$ for over one hour. If this level is unhealthy for us, we can predict its impact on an animal recovering from surgery.

The European deer was the one that concerned us more. The music was loud enough for us to identify the lyrics on the cam trap. In the other enclosures it was not always possible. On EV days, he almost didn't stop walking, for instance, from Saturday 9pm to Sunday 3:30am, dragging his activity clock. He sat to ruminate on Monday. The curassow had also the nocturnal resting interrupted during the music playing, but it was not possible to attribute that to the music or to the alarm calling of other avians. In the wild, going to the floor at night would be risky (Sick, 1970). Only during the NE we saw social displays and species specific calls that may have positive effects on captive animals (Broom, 2011).

About the soundscape, it was richer in the number of species calling in EV but it should be evaluated caustelously, differing alarm calls and courtship and other social calls. Calling is physiologically expensive and may attract eavesdroppers and predators (Slabbekoorn and Ripmeester, 2008; Chan and Blumstein, 2011; Monticelli, 2021). It may not affect animals in a zoo, but the area in an ecological reserve. There were diurnal species vocalizing during the dark in EV and in a long time window (9:50pm-00:50a); and there were also those that called only in EV condition. That changing in patterns should be longer monitored. 
We are a noisy species, but we are also responsible and solidary. No animal died during the festivities in PMMSB, as reported by the zoo. But it says nothing about welfare quality and its negative long term effects on health (Broom, 2011). The discomfort we identified is commonly associated with a breakdown of physiological homeostasis, with changes in levels of endocrine parameters that may trigger pathologies that develop slower than instantaneous death.

The Forest and Municipal Zoo Fábio Barreto configures a zone sensitive to noise: it contains species that can be harmed by the acute or chronic exposure to noise. Besides the loud music and thousands of people talking, there is an increase in vehicle traffic in the APA that, in addition to generating air and noise pollution, increases the chance of running over freeliving animals. Even now that the festivities were legally stopped, the PMMSB urges for measures to mitigate the impact caused by traffic on Avenida Capitão Salomão (close to the elephant and big cats). It is possible to implement measures to alleviate noise, such as the production of sound barriers (Slabbekoorn \& Ripmeester 2008) or the closure of roads during the night period (Groot Bruinderink et al., 2002; Makarewicz \& Kokowski 2007). It just needs human initiatives. 


\section{References}

ABNT Acústica 2000. Acoustics - Evaluation of noise in inhabited areas aiming the comfort of the community - Procedure. Projeto NBR 10151:1999. Comitê Brasileiro de Construção Civil, Comissão de Estudo de Desempenho Acústico de Edificações Available at NBR-10.151-Avaliacao-do-ruido-em-areas-habitadas.pdf

Baldwin, A. L., Primeau, R. L., \& Johnson, W. E. (2006). Effect of noise on the morphology of the intestinal mucosa in laboratory rats. Journal of the American Association for Laboratory Animal Science, 45(1), 74-82.

Barber, J. R., Burdett, C.L., Reed, S.E., Warner, K.A., Formichella, C., Crooks, K.R., Theobald, D.M., Fristrup, K.M. (2011). Anthropogenic noise exposure in protected natural areas: estimating the scale of ecological consequences. Landscape Ecology, 26, pp. 1281-1295.

Barber, J. R., Crooks, K. R., \& Fristrup, K. M. (2010). The costs of chronic noise exposure for terrestrial organisms. Trends in ecology \& evolution, 25(3), 180-189.

Berglund, B., Lindvall, T., Schiele, D. H., \& World Health Organization. (1999). Guidelines for community noise. WHO- expert task force meeting, London, UK. Available at https://www.who.int/docstore/peh/noise/Comnoise-1.pdf

Blickley 1, J. L., Patricelli 2, G. L. (2010). Impacts of anthropogenic noise on wildlife: research priorities for the development of standards and mitigation. Journal of International Wildlife Law \& Policy, 13(4), 274-292.

Bradbury, J. W., \& Vehrencamp, S. L. (2000). Economic models of animal communication. Animal behaviour, 59(2), 259-268.

Broom, D.M. A History of Animal Welfare Science. Acta Biotheor 59, 121-137 (2011). https://doi.org/10.1007/s10441-011-9123-3

Brumm, H., \& Slabbekoorn, H. (2005). Acoustic communication in noise. Advances in the Study of Behavior, 35, 151-209.

Burg, J., Romney, J., \& Schwartz, E. (2017). Digital Sound \& Music: Concepts, Applications, and Science. Franklin, Beedle \& Associates.

Carr, C. E., \& Christensen-Dalsgaard, J. (2015). Sound localization strategies in three predators. Brain, behavior and evolution, 86(1), 17-27.

Chan, A. A. Y. H., \& Blumstein, D. T. (2011). Attention, noise, and implications for wildlife conservation and management. Applied Animal Behaviour Science, 131(1-2), 1-7. 
Chepesiuk, R. (2005). Decibel hell: the effects of living in a noisy world. Environmental Health Perspective, 113 (1): 34-41.

Duarte, M. H., Vecci, M. A., Hirsch, A., \& Young, R. J. (2011). Noisy human neighbors affect where urban monkeys live. Biology Letters, 7(6), 840-842.

Dwisetyo, B., Rusjadi, D., Palupi, M. R., Putri, C. C., Utomo, F. B., Prasasti, N. R., \& Hermawanto, D. (2021, April). Comparison of sound level meter calibration for frequency weighting parameter using coupler method. In Journal of Physics: Conference Series (Vol. 1896, No. 1, p. 012011). IOP Publishing.

Ey, E., \& Fischer, J. (2009). The "acoustic adaptation hypothesis"-a review of the evidence from birds, anurans, and mammals. Bioacoustics, 19(1-2), 21-48.

Fidino, M., Gallo, T., Lehrer, E. W., Murray, M. H., Kay, C., Sander, H. A., ... \& Magle, S. B. (2020). Landscape-scale differences among cities alter common species' responses to urbanization. Ecological Applications, n/a (n/a), e2253. doi: https://doi. org/10.1002/eap, 2253.

Francis, C. D., \& Barber, J. R. (2013). A framework for understanding noise impacts on wildlife: an urgent conservation priority. Frontiers in Ecology and the Environment, 11(6), 305-313.

Graydon, K., Waterworth, C., Miller, H., \& Gunasekera, H. (2019). Global burden of hearing impairment and ear disease. The Journal of Laryngology \& Otology, 133(1), 1825 .

Grinnell, J., \& McComb, K. (2001). Roaring and social communication in African lions: the limitations imposed by listeners. Animal Behaviour, 62(1), 93-98.

Guilford, T., \& Dawkins, M. S. (1991). Receiver psychology and the evolution of animal signals. Animal behaviour, 42(1), 1-14.

Kotchetkoff-Henriques, O., Joly, C. A., \& Bernacci, L. C. (2005). Relação entre o solo e a composição florística de remanescentes de vegetação natural no Município de Ribeirão Preto, SP. Brazilian Journal of Botany, 28(3), 541-562.

Kotchetkoff-Henriques, O., Pereira, M., Polo L., Sakamoto, C. H. V.; Tozzo, M. G. 2018. Gigantes do Bosque - Árvores do Parque Municipal do Morro de São Bento, 124p.

Lorenz, K. Z. (1958). The evolution of behavior. Scientific American, 199(6), 67-82.

Montgomerie, R., \& Weatherhead, P. J. (1997). How robins find worms. Animal behaviour, 54(1), 143-151. 
Möstl, E. and Palme, R. Hormones as indicators of stress. Domest Anim Endocrinol. 2002 Jul;23(1-2):67-74. doi: 10.1016/s0739-7240(02)00146-7. PMID: 12142227.

Neuweiler, G. (1989). Foraging ecology and audition in echolocating bats. Trends in ecology \& evolution, 4(6), 160-166.

Ordoñez, R., Aranda de Toro, M. A., \& Hammershoi, D. (2010, June). Time and frequency weighting and the assessment of sound exposure. In INTER-NOISE and NOISECON Congress and Conference Proceedings (Vol. 2010, No. 7, pp. 4426-4435). Institute of Noise Control Engineering.

Parks, S. E., Johnson, M. P., Nowacek, D. P., \& Tyack, P. L. (2012). Changes in vocal behavior of North Atlantic right whales in increased noise. In The Effects of Noise on Aquatic Life (pp. 317-320). Springer, New York, NY.

Patricelli, G. L., \& Blickley, J. L. (2006). Avian communication in urban noise: causes and consequences of vocal adjustment. The Auk, 123(3), 639-649.

Payne, R. S. (1971). Acoustic location of prey by barn owls (Tyto alba). Journal of Experimental Biology, 54(3), 535-573.

Pijanowski, B. C., Villanueva-Rivera, L. J., Dumyahn, S. L., Farina, A., Krause, B. L., Napoletano, B. M., ... \& Pieretti, N. (2011). Soundscape ecology: the science of sound in the landscape. BioScience, 61(3), 203-216.

Rice, W. R. (1982). Acoustical location of prey by the marsh hawk: adaptation to concealed prey. The Auk, 99(3), 403-413.

Rodden, M. (2007). Maned Wolf Husbandry Manual. Melissa Rooden (Ed.). Maned Wolf SSP Management Committee. Accessed 2021, June at https://aszk.org.au/wpcontent/uploads/2020/06/Maned-Wolf-Chrysocyon-brachyurus-Maned-WolfSSP-2007.pdf

Sick, H. (1970). Notes on Brazilian cracidae. The Condor, 72(1), 106-108.

Slabbekoorn, H., \& Ripmeester, E. A. P. (2008). Birdsong and anthropogenic noise: implications and applications for conservation. Molecular Ecology, 17(1), 72-83.

Śliwińska-Kowalska, M., \& Davis, A. (2012). Noise-induced hearing loss. Noise and Health, 14(61), 274.

Srbek-Araujo, A. C., Silveira, L. F., \& Chiarello, A. G. (2012). The red-billed curassow (Crax blumenbachii): social organization, and daily activity patterns. The Wilson Journal of Ornithology, 124(2), 321-327.

Stankowich, T. (2008). Ungulate flight responses to human disturbance: a review and metaanalysis. Biological Conservation, 141(9), 2159-2173. 
Van Raaij, M. T., Oortgiesen, M., Timmerman, H. H., Dobbe, C. J., \& Van Loveren, H. E. N. K. (1996). Time-dependent differential changes of immune function in rats exposed to chronic intermittent noise. Physiology \& behavior, 60(6), 1527-1533.

Warren, P. S., Katti, M., Ermann, M., \& Brazel, A. (2006). Urban bioacoustics: it's not just noise. Animal behaviour, 71(3), 491-502.

Wong, W. (2010). The Risk Management of Safety and Dependability: A Guide for Directors, Managers and Engineers. Elsevier.

World Health Organization. (2017). Global costs of unaddressed hearing loss and costeffectiveness of interventions: a WHO report, 2017. World Health Organization. 
Figure 1. Top: Aerial image of the Fábio Barreto Zoo and Alto do São Bento Square, where the 11th Festitalia took place in Ribeirão Preto. The flags indicate the georeferenced SPL measurement points (GPS Garmin eTrex 30, +10 meters accuracy). The Bio/quarantine point would be next to the veterinary hospital. In yellow and red are indicated the points where the sound level reached the limit of intense irritation, subject to health risk after 8 and 4 hours of exposure, respectively. The recorder was installed in the quarantine sector. The enclosures monitored by video (camera icon) were the ocelot (next to the Irara flag), the European deer (Hospital veterinarian), curassows (Birds of prey), maned wolf (Bio/quarantine), marsh deer (Gate 4), and anteaters (Irara).

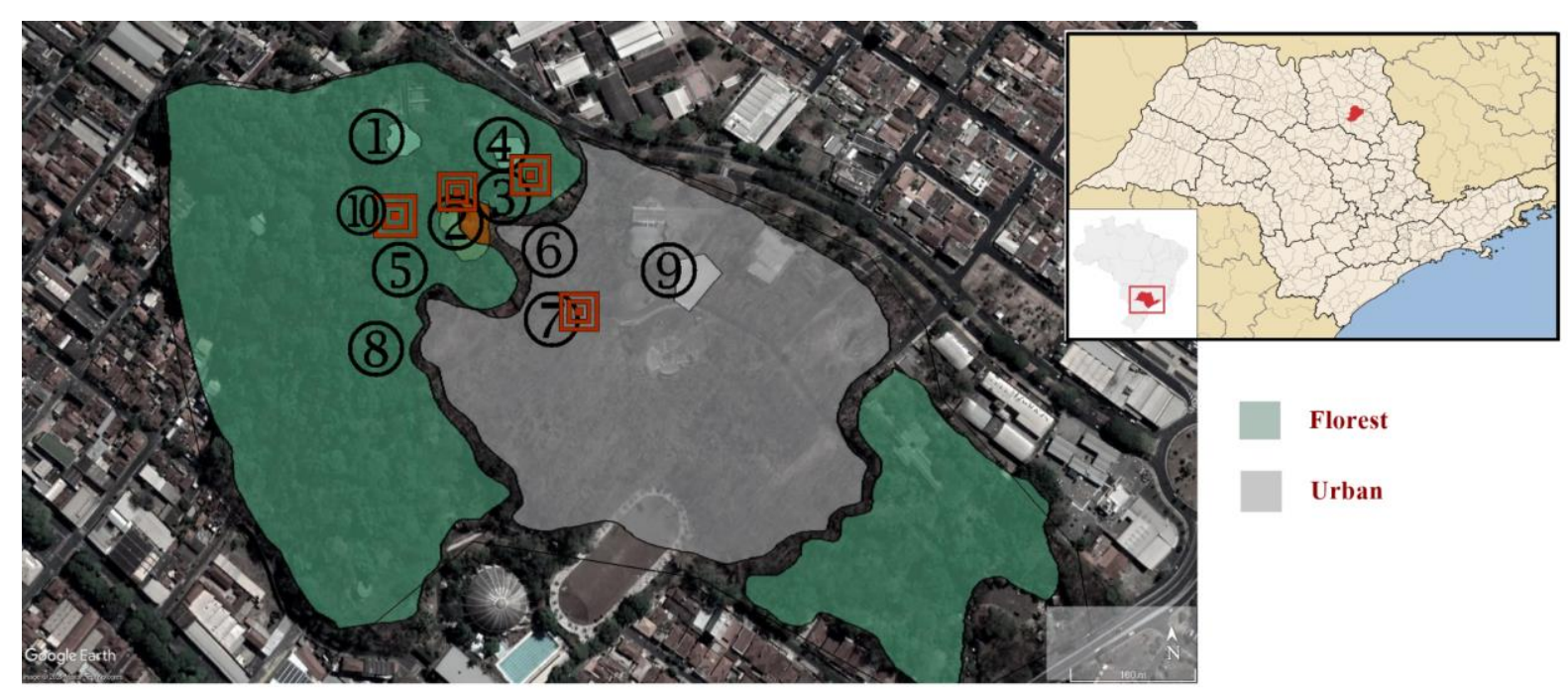
Legend
1. Capybara bridge
4. Elephant enclosure
7. Gate 4
10. Irara
2. Hospital veterinarian
5. Bird's of prey
8. Japanese garden
3. Bio/quarantine
6. Water tank
9. Stage (noise source)

Image obtained through Google Earth in September/2016. A photograph of the public at Festitalia in 2016 is available at http://festitaliaribeiraopreto.blogspot.com/2016/. 


\section{Figure 2.}

Photograph taken from vídeo registered by the cam traps of three enclosures and their residents: above, two images from the male Dama dama enclosure, one at night, with a rat over a door (left, top left) and at daylight. Below, the maned wolf male and the two males ocelots, in daylight.

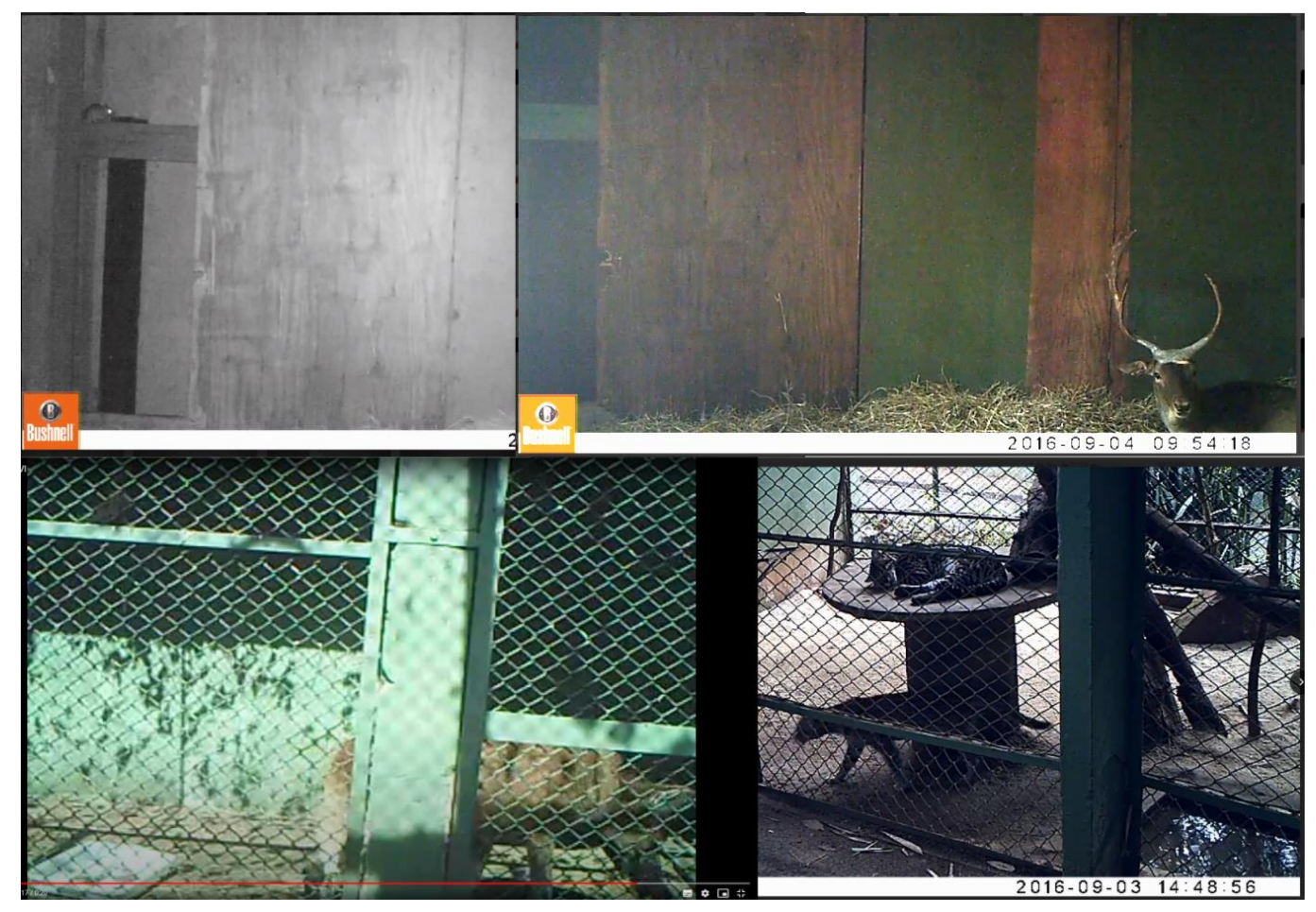


Figure 3. Percentage of time the European deer spent with different activities on Saturday and Sunday at EV (Festitalia) and NE (control) conditions. Included in resting is ruminating, when performed layed down (e.g., Fig. 2). Other activities include head movements, moving around, self-cleaning, standing upright, rubbing the head against substrate, knocking the floor (a defensive act) and head shaking.

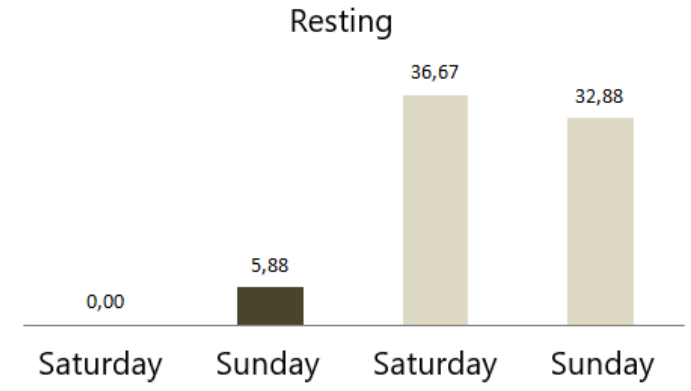

Foraging

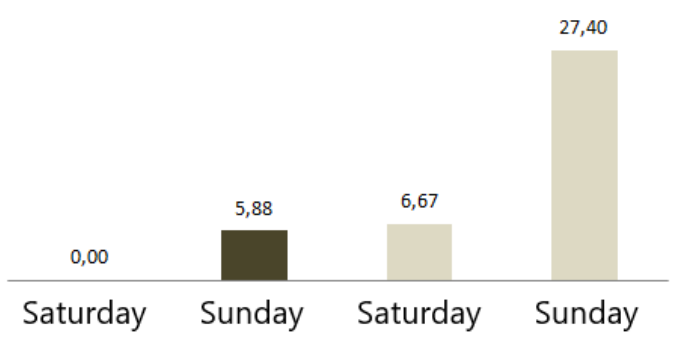

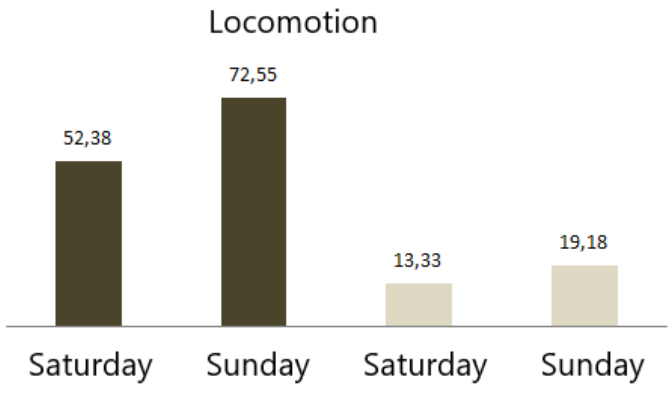

Other activities

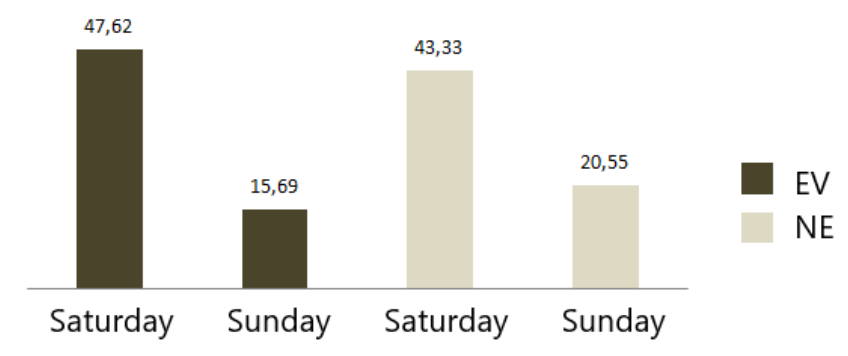




\section{Figure 4}

Percentage of time the Curassow spent with different activities on Saturday and Sunday at EV (Festitalia) and NE (control) conditions.
EV
NE
EV
NE

100

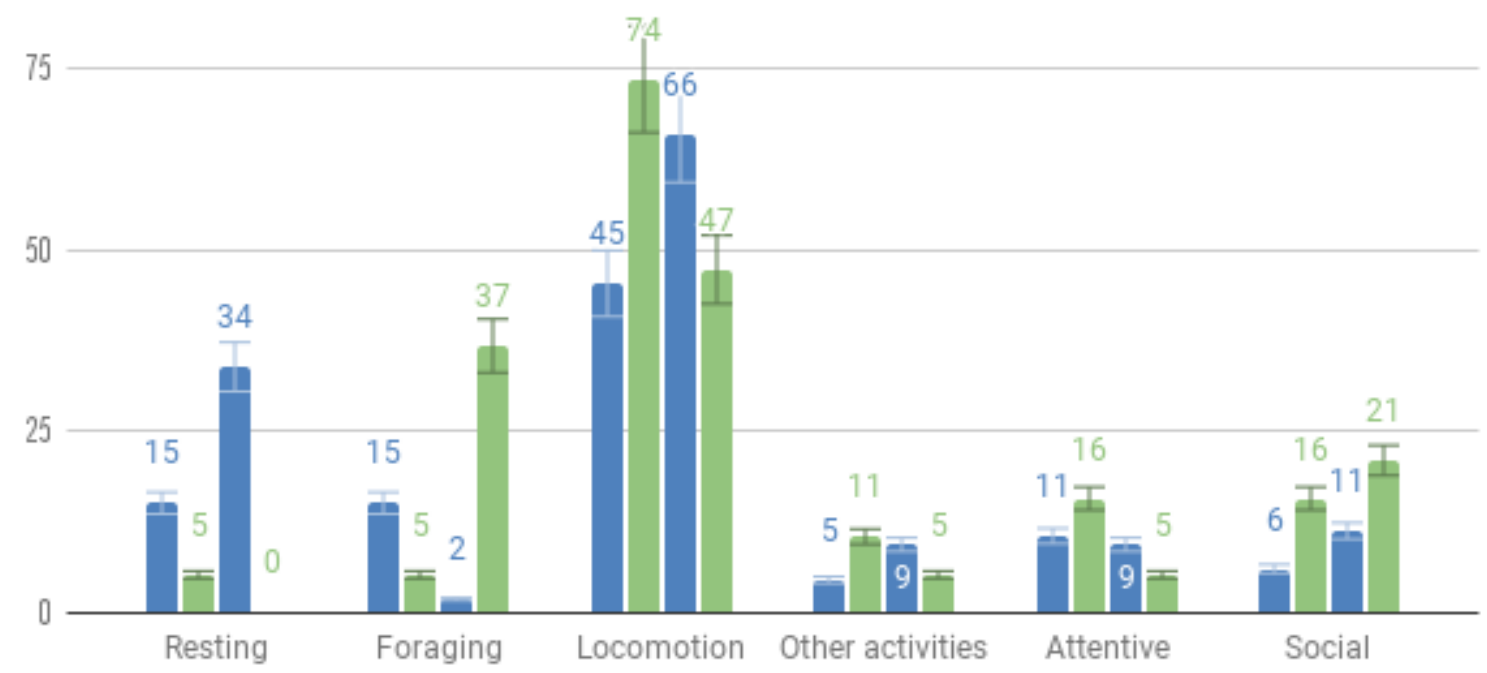




\section{Figure 5}

Percentage of the number of shoots the maned wolf spent with different activities on EV (Festitalia) and NE (control) conditions.

EV $\square$ NE

80

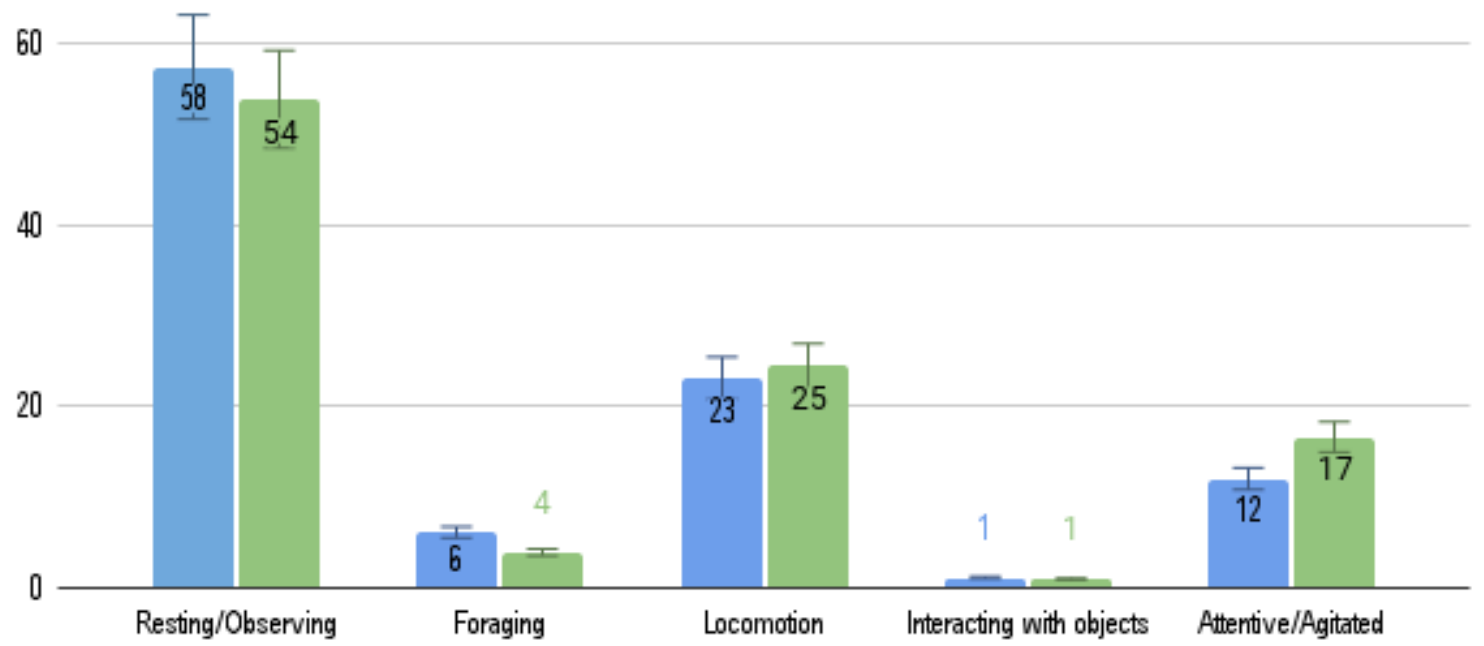




\section{Figure 6}

Absolute number of shoots (occurrences) the ocelots spent with different activities on EV (Festitalia) and NE (control) conditions (darker colors of blue and green, respectively) and in a comparable size sample window of analys, in clearer colors of blue (EV Sunday) and green (Saturday NE).

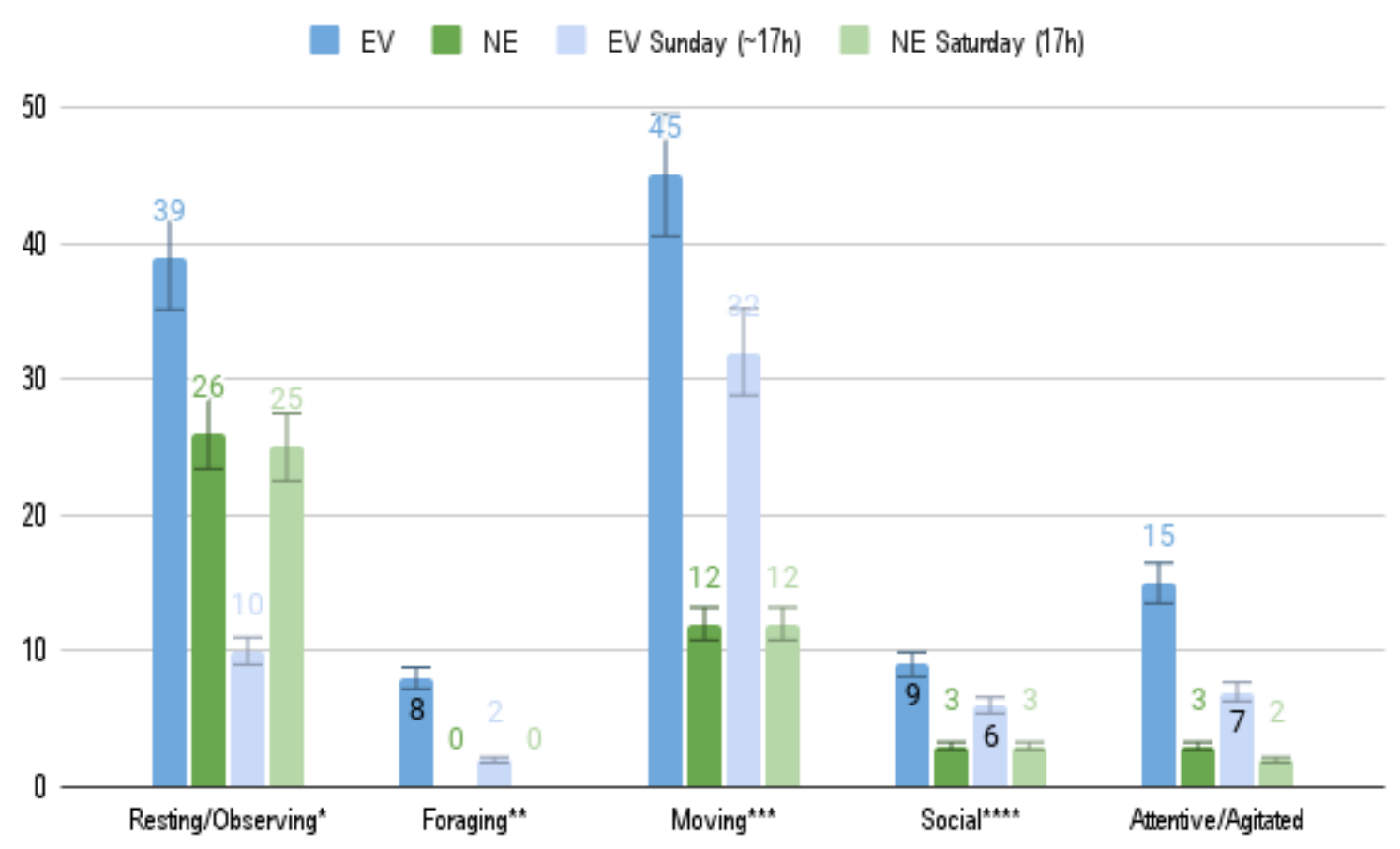


Table 1. Festitalia 2016 Schedule of cultural activities obtained in 2016 at http://festitaliaribeiraopreto.blogspot.com/2016/

\section{August 5th - Friday}

7:00 pm Opening of the Italian Immigrant Memorial Exhibition.

7:30 pm Official opening ceremony with Choir presentation.

8:30 pm Typical Dance Presentation.

9:20 pm Musical Show.

\section{August 6th - Saturday}

Noon Tenor musical lunch and Painting on open-air.

1:00 pm Culinary workshop.

3:00 pm Venezian masks workshop and Musical Entertainment.

4:30 pm Culinary Contest.

5:00 pm Lecture.

5:30 pm Typical Dance Choreography (with tarantellas)

6:00 pm Musical

7:15 pm Folk Group presentation with choreography.

8:00 pm Musical Show

9:00 pm Musical Show

\section{September 8th - Sunday}

11:30 am Holy Mass in Italian

Noon Musical Lunch and Painting on open-air

3:00 pm Musical Entertainment

3:00 pm Lecture

4:30 pm Dancing with tarantellas

4:30 pm Culinary Contest

5:00 pm Musical show

6:00 pm Musical theater.

7:15 pm Folk Group presentation with choreography.

8:00 pm Culinary contest award

8:15 pm Musical show

8:45 pm Musical Show (tenor) 
Table 2. Auditory frequency range perception of mammals and birds. Table drawn from Warfield 1973, Fay 1988 and Fay \& Popper 1994. Humans perceive sounds from very low frequency, until $25 \mathrm{kHz}$, nevertheless, the SPL A-weighting curve considers the log distribution of our most accurate range of hearing.

\begin{tabular}{|c|c|c|c|}
\hline \multicolumn{2}{|c|}{ Animal } & \multicolumn{2}{|c|}{ Auditory frequency range perception $(\mathrm{Hz})$} \\
\hline & & Low-frequency limit & $\begin{array}{c}\text { High-frequency } \\
\text { limit }\end{array}$ \\
\hline Canary & Avians & 250 & 10000 \\
\hline Cockatiel & & 250 & 8000 \\
\hline Parakeet & & 200 & 8500 \\
\hline Zebra finch & & $<250$ & 7000 \\
\hline Turkey & & $<250$ & 7000 \\
\hline Pigeon & & $<125$ & 6600 \\
\hline Budgerigar & & 125 & 8000 \\
\hline Cat & Mammals & 55 & 79000 \\
\hline Rabbit & & 96 & 49000 \\
\hline Guinea pig & & 47 & 49000 \\
\hline Dog & & 67 & 44000 \\
\hline Cow & & 23 & 35000 \\
\hline Horse & & 55 & 33500 \\
\hline Goat & & 100 & 30000 \\
\hline
\end{tabular}


Human 
Table 3. Means (standard deviations) and minimum and maximum values of the peak exposition values of $\mathrm{dBC}$. As a reference, for eight hours of exposure, $137 \mathrm{~dB}(\mathrm{C})$ would be as damaging as $85 \mathrm{~dB}(\mathrm{~A})$, for humans. The measures were recorded in the 12 localities (see Fig. 1) in EV and NE. In EV we separated the first and the second tour, one with a man on the microphone and another during the music show. The values were obtained from 20 SPL registries spaced by 10s-intervals. Dark cells indicate the higher values.

\begin{tabular}{|c|c|c|c|c|c|c|}
\hline \multirow{3}{*}{ Localities } & \multicolumn{4}{|c|}{ EV } & \multicolumn{2}{|c|}{$\mathbf{N E}$} \\
\hline & micro| & hone & music & show & & \\
\hline & $\begin{array}{c}\text { Average } \\
\text { (sd) }\end{array}$ & $\min -m a x$ & $\begin{array}{c}\text { Average } \\
\text { (sd) }\end{array}$ & $\min -m a x$ & $\begin{array}{c}\text { Average } \\
\text { (sd) }\end{array}$ & $\min -\max$ \\
\hline $\begin{array}{l}\text { Stage front } \\
\text { Stage }\end{array}$ & $99,59(11,4)$ & $79,9->110$ & $106,2(4,1)$ & $\begin{array}{l}100,9- \\
>110,0\end{array}$ & $65,89(2,38)$ & $62,3-70,5$ \\
\hline behind & $92,17(11,7)$ & $69,7->110$ & $100,4(3,2)$ & $92,7-104,4$ & $66,81(2,63)$ & $62,9-72,1$ \\
\hline Gate 4 & $83,26(9,3)$ & $71,3-94,5$ & $84,5(9,1)$ & $66,0-95,0$ & $62,52(1,26)$ & $60,6-65,1$ \\
\hline Elephants & $75,26(4,5)$ & $64-80,1$ & $79,5(2,5)$ & $74,2-82,3$ & $70,09(5,48)$ & $62,1-84,3$ \\
\hline Big Cats & $69,45(4,6)$ & $62-77,7$ & $71,8(4,1)$ & $67,4-80,1$ & $68,36(5,25)$ & $60,7-78,0$ \\
\hline $\begin{array}{l}\text { Water tank } \\
\text { Veterinary }\end{array}$ & $71,94(5,9)$ & $64,6-78,9$ & $88,02(4,2)$ & $79,2-92,3$ & $64,95(3,11)$ & $60,9-72,0$ \\
\hline $\mathrm{H}$ & $66,06(3,4)$ & $59,8-70,3$ & $81,52(3,2)$ & $76,9-87,7$ & $58,62(1,60)$ & $55,9-62,1$ \\
\hline $\begin{array}{l}\text { Japanese } \\
\text { garden }\end{array}$ & $65,51(3,4)$ & $61,3-73,5$ & $71,4(5,1)$ & $64,2-77,9$ & $63,00(1,75)$ & $59,5-66,4$ \\
\hline $\begin{array}{l}\text { Birds of } \\
\text { prey }\end{array}$ & $64,35(2,9)$ & $59,4-67,9$ & $74,5(2,5)$ & $70,7-78,1$ & $59,91(1,63)$ & $57,7-64,9$ \\
\hline $\begin{array}{l}\text { Biology } \\
\text { (nursery) }\end{array}$ & & & $77,2(2,3)$ & $73,2-80,5$ & $59,48(1,40)$ & $57,3-61,6$ \\
\hline Ocelots & $63,13(2,4)$ & $59,4-67,2$ & $71,9(4,2)$ & $64,1-76,1$ & $58,82(1,12)$ & $56,9-60,6$ \\
\hline $\begin{array}{l}\text { Capybara } \\
\text { bridge }\end{array}$ & $63,34(2,0)$ & $59,9-66,4$ & $66,4(4,5)$ & $60,7-72,0$ & $61,79(4,23)$ & $57,5-73,9$ \\
\hline
\end{tabular}




\section{Table 4.}

Species' popular and scientific names (according to ZFB) and their taxonomic position (Order: Família), and the number of vídeo recordings (n) generated by movement sensor activation (shoots) in EV and NE weekends, per day. Shoot rate represents the number of videos/recording periods (from 7 to $24 \mathrm{~h}$ ).

$\begin{array}{ll}\text { Festitalia } & \text { A weekend } \\ (\mathrm{EV}) & (\mathrm{NE})\end{array}$

\begin{tabular}{|c|c|c|c|c|c|}
\hline \multicolumn{2}{|l|}{$\begin{array}{l}\text { Popular name } \\
\text { (number of } \\
\text { individuals) }\end{array}$} & \multirow{2}{*}{$\frac{\text { video/day }}{--}$} & \multirow{2}{*}{$\frac{\text { shoots rate }}{--}$} & \multirow{2}{*}{$\frac{\text { video/day }}{6}$} & \multirow{2}{*}{$\begin{array}{c}\text { shoots rate } \\
0.9\end{array}$} \\
\hline Fallow deer (1) & Friday & & & & \\
\hline Dama dama & Saturday & 28 & 2.5 & 32 & 1.3 \\
\hline \multicolumn{6}{|l|}{ Artiodactyla: } \\
\hline \multirow[t]{3}{*}{ Cervidae } & Sunday & 57 & 2.4 & 76 & 3.2 \\
\hline & Monday & 31 & 2.1 & 26 & 1.9 \\
\hline & Total & \multicolumn{2}{|c|}{$\mathrm{n}=116(\sim 50 \mathrm{~h})$} & \multicolumn{2}{|c|}{$\mathrm{n}=140(\sim 79 \mathrm{~h})$} \\
\hline Curassows (2) & Friday & 4 & 0.4 & 0 & 0.0 \\
\hline $\begin{array}{l}\text { Crax fasciolata } \\
\text { Galliformes: }\end{array}$ & Saturday & 66 & 2.8 & 19 & 1.1 \\
\hline \multirow[t]{3}{*}{ Cracidae } & Sunday & 53 & 2.2 & 19 & 0.8 \\
\hline & Monday & 4 & 0.3 & 10 & 0.7 \\
\hline & Total & \multicolumn{2}{|c|}{$\mathrm{n}=133(\sim 72 \mathrm{~h})$} & \multicolumn{2}{|c|}{$\mathrm{n}=48(\sim 62 \mathrm{~h})$} \\
\hline Maned-wolf (1) & Friday & -- & -- & 30 & 4.3 \\
\hline $\begin{array}{l}\text { Chrysocyon } \\
\text { brachyurus }\end{array}$ & Saturday & 55 & 5.5 & 63 & 9.0 \\
\hline \multirow[t]{3}{*}{ Carnivora: Canidae } & Sunday & 119 & 5.0 & 7 & 3.5 \\
\hline & Monday & 141 & 9.4 & -- & -- \\
\hline & Total & \multicolumn{3}{|c|}{$\mathrm{n}=315(\sim \mathrm{h})$} & $\mathrm{n}=100(\sim \mathrm{h})$ \\
\hline Ocelot (3) & Friday & -- & -- & 2 & -- \\
\hline Leopardus pardalis & Saturday & 42 & 3.8 & 45 & 2.6 \\
\hline \multirow[t]{2}{*}{ Carnivora: Felidae } & Sunday & 54 & 3.2 & -- & -- \\
\hline & Monday & 22 & 3.1 & -- & -- \\
\hline
\end{tabular}



Table 5. Biological sounds of birds and mammals captured and identified in Friday recordings, in $\mathrm{EV}$ and $\mathrm{NE}$ by $\mathrm{SM}$, from 5:50 pm. When it is possible to reach recognition at the species level, the name is offered. The numbers in parentheses represent the occurrences of each type. $\mathrm{NI}$ indicates unidentified vocalizations. When there was rain, it was indicated. Speech into the microphone was noted from 18:25, and the sound

The party must have ended at 10:30 pm.

\begin{tabular}{|c|c|c|}
\hline $\begin{array}{l}\text { Horário da } \\
\text { gravação }\end{array}$ & 11A FESTITÁLIA & SEM FESTA \\
\hline \multirow{10}{*}{$17: 50$ às $18: 50$} & \multicolumn{2}{|c|}{ Asa-branca, Patagioenas picazuro (7) Asa-branca (2) } \\
\hline & Arara, Ara arauna (15) & Arara (5) \\
\hline & Bem-te-vi, Pitangus sulphuratus (1) & Bem-te-vi (2) \\
\hline & Pavão $(87)$ & Pavão (110) \\
\hline & Papagaio, Amazona amazonica (2) & Psitacideo? (11) \\
\hline & Coruja (1) & Urutau (4) \\
\hline & \multicolumn{2}{|l|}{ Corujinha-do-mato, Megascops } \\
\hline & Saracura, Aramides cajanae (1) & NI (19) \\
\hline & \multicolumn{2}{|l|}{ NI (2) } \\
\hline & Leão (1) & \\
\hline \multicolumn{3}{|c|}{ Total ocorrencias } \\
\hline \multirow{4}{*}{$18: 50$ às $19: 50$} & Pavão $(8)$ & Pavão (57) \\
\hline & Psitacideo? (2) & NI (38) \\
\hline & NI $(20)$ & \\
\hline & Leão $(1)$ & \\
\hline Total ocorrencias & 31 & 95 \\
\hline \multirow[t]{6}{*}{$19: 50$ às $20: 50$} & Pavão (2) & Pavão (39) \\
\hline & Corujinha-do-mato, Megascops & \\
\hline & choliba (1) & Coruja-buraqueira (4) \\
\hline & NI (4) & NI (35) \\
\hline & Arara, Ara arauna (1) & \\
\hline & Leão (1) & \\
\hline Total ocorrencias & 9 & 78 \\
\hline \multirow[t]{3}{*}{$20: 50$ às $21: 50$} & Pavão (9) & Pavão (50) \\
\hline & NI (3) & NI (14) \\
\hline & & Coruja-buraqueira (2) \\
\hline Total ocorrencias & 12 & 66 \\
\hline \multirow[t]{4}{*}{$21: 50$ às $22: 50$} & Psitacideo? (1) & Pavão (7) \\
\hline & NI (1) & NI (31) \\
\hline & Lobo-guará (1) & \\
\hline & Leđ̃o (1) & \\
\hline Total ocorrencias & 4 & 38 \\
\hline \multirow[t]{5}{*}{$22: 50$ às $23: 50$} & Psitacideo? (3) & Pavão (18) \\
\hline & Movimento no recinto (2) & Urutau (3) \\
\hline & Bater-de-asas (1) & NI (28) \\
\hline & NI (3) & \\
\hline & Lobo-guará (1) & \\
\hline Total ocorrencias & Fovo gewar (1) & 49 \\
\hline \multirow[t]{6}{*}{$23: 50$ às $00: 50$} & Pavão (1) & Pavão (6) \\
\hline & NI (3) & NI (6) \\
\hline & Saracura, Aramides cajanae (1) & \\
\hline & $\begin{array}{l}\text { coruja (1) } \\
\text { Psitacideo? (2) }\end{array}$ & \\
\hline & Lobo-guará (1) & \\
\hline & Leão (1) & \\
\hline Total ocorrencias & 10 & 12 \\
\hline
\end{tabular}


